\title{
Chromosome studies in the genus Mikania (Asteraceae)
}

\author{
Paulo M. Ruas ${ }^{1}$, Claudete F. Ruas ${ }^{1}$, Eliane M.D. Maffei ${ }^{1}$, Maria A. Marin-Morales ${ }^{2}$ \\ and Margarida L.R. Aguiar-Perecin ${ }^{3}$ \\ ${ }^{1}$ Departamento de Biologia Geral, CCB, Universidade Estadual de Londrina, 86051-990 Londrina, PR, Brasil. Send correspondence to P.M.R. \\ ${ }^{2}$ Departamento de Ciências Biológicas, UNESP, Campus de Assis, Assis, SP, Brasil. \\ ${ }^{3}$ Departamento de Genética, Escola Superior de Agricultura “Luiz de Queiroz", USP, Piracicaba, SP, Brasil.
}

\section{INTRODUCTION}

Mikania is the largest genus of the tribe Eupatorieae with about 430 species distributed in the pantropics, temperate America, and Southern Africa, but with its two major diversity centers in the highlands of southeastern Brazil and the eastern foothills of the Andes from Bolivia to Colombia (King and Robinson, 1987; Holmes, 1995). The genus is widely distributed in Brazil with about 200 described species (Barroso, 1958, 1986), many of which are endemic to southern Brazil, but with a greater number of species being found in Amazon region.

The species are characterized by their capitula which is composed of four florets and an involucre composed of four phyllaries that is subtended by a subinvolucral bract. There is no variation from this basic organization, and specific differences mostly involve the type of capitulescence, size of habit, shape of organs, and plant texture (Holmes, 1995).

Until 1987 chromosome studies of the genus have been limited to chromosome counts, but such counts are available for only about $10 \%$ of the species (Gaiser, 1954; Mangenot and Mangenot, 1958; Turner, 1962; Turner et al., 1967; Baquar, 1967-1968; Mitra and Datta, 1967; Sharma and Sakar, 1967-1968; Coleman, 1968; Nevlin, 1969; Powell and King, 1969; King et al., 1976; Turner et al., 1979; Nauman, 1981; Mathew and Mathew, 1983; Strother, 1983; Waisman et al., 1984).

The first karyotype studies in Mikania were made by Ruas and Ruas (1987) on six species from which they suggested that there was an evolutionary trend in the genus towards the formation of aneuploid and polyploid series. In a study of ten species of Mikania Ruas (1989) and Ruas and Aguiar-Perecin (1997) proposed a correlation between morphological and chromosomal evolution, while an analysis of 12 cytotypes of Mikania micrantha by Maffei (1996) showed that the same evolutionary mechanisms that occur among species also occur at intraspecific level, results also seen in a study of two populations of $M$. cordifolia by Maffei et al. (1999a).

In this review, the chromosomal evolution of the genus Mikania is discussed based on currently available data.

\section{KARYOLOGICAL ASPECTS}

Thirty-two taxa of Mikania have so far been examined, including 16 different species (Ruas and Ruas, 1987; Ruas, 1989; Ruas and Aguiar-Perecin, 1997), 14 populations of M. micrantha (Ruas and Ruas, 1987; Maffei, 1996; Maffei et al., 1998, 1999b) and two populations of $M$. cordifolia (Ruas and Ruas, 1987; Maffei et al., 1999a). All the karyotypes were characterized by the presence of a secondary constriction in the long arm of chromosome 1 , and Ruas and Ruas (1987), in the analysis of six species, proposed that this secondary constriction should be considered a cytological marker for the genus. In six tetraploid cytotypes of M. micrantha (Table I) a secondary constriction was observed in chromosomes pairs 1 and 2. In $M$. sessilifolia, a hexaploid species, this cytological marker was seen in the first three pairs of chromosomes. Ruas (1989) and Ruas and Aguiar-Perecin (1997) showed (using the silver staining methodology) that the nucleolar-organizing region is located in the secondary constriction of the long arm of chromosome 1 , and it seems that this pattern has been conserved in the evolution of the karyotypes of Mikania as proposed by Ruas and Ruas (1987).

In all karyotypes so far examined chromosome 1 ranges in length from 2.00 to $5.20 \mu \mathrm{m}$ and the arm ratio varies from 1.40 (M. trinervis) to $2.60 \mu \mathrm{m}$ (M. micrantha from Praia de Ipanema, Paraná State, Brazil), which suggests that structural rearrangements such as the deletion or addition of chromatin might have occurred during the evolution of genus Mikania. C-banding analysis showed a large block of heterochromatin near the secondary constriction of chromosome 1 in a population of $M$. micrantha from Piracicaba (São Paulo State, Brazil), while another population of this species showed a smaller chromosome pair 1 accompanied by the total absence of heterochromatic bands. The presence or absence of heterochromatin may in part explain the variation in size observed in chromosome 1.

In all the species and cytotypes so far studied (Ruas and Ruas, 1987; Ruas, 1989; Maffei, 1996; Ruas and AguiarPerecin, 1997; Maffei et al., 1998, 1999b) the smallest pair of chromosomes ranges in length from 0.60 to 1.50 $\mu \mathrm{m}$ and the arm ratio varies from 1.20 (M. micrantha from Apucarana) to $2.80 \mu \mathrm{m}$ (M. cordifolia and M. glomerata), which suggests that structural rearrangements such as DNA 


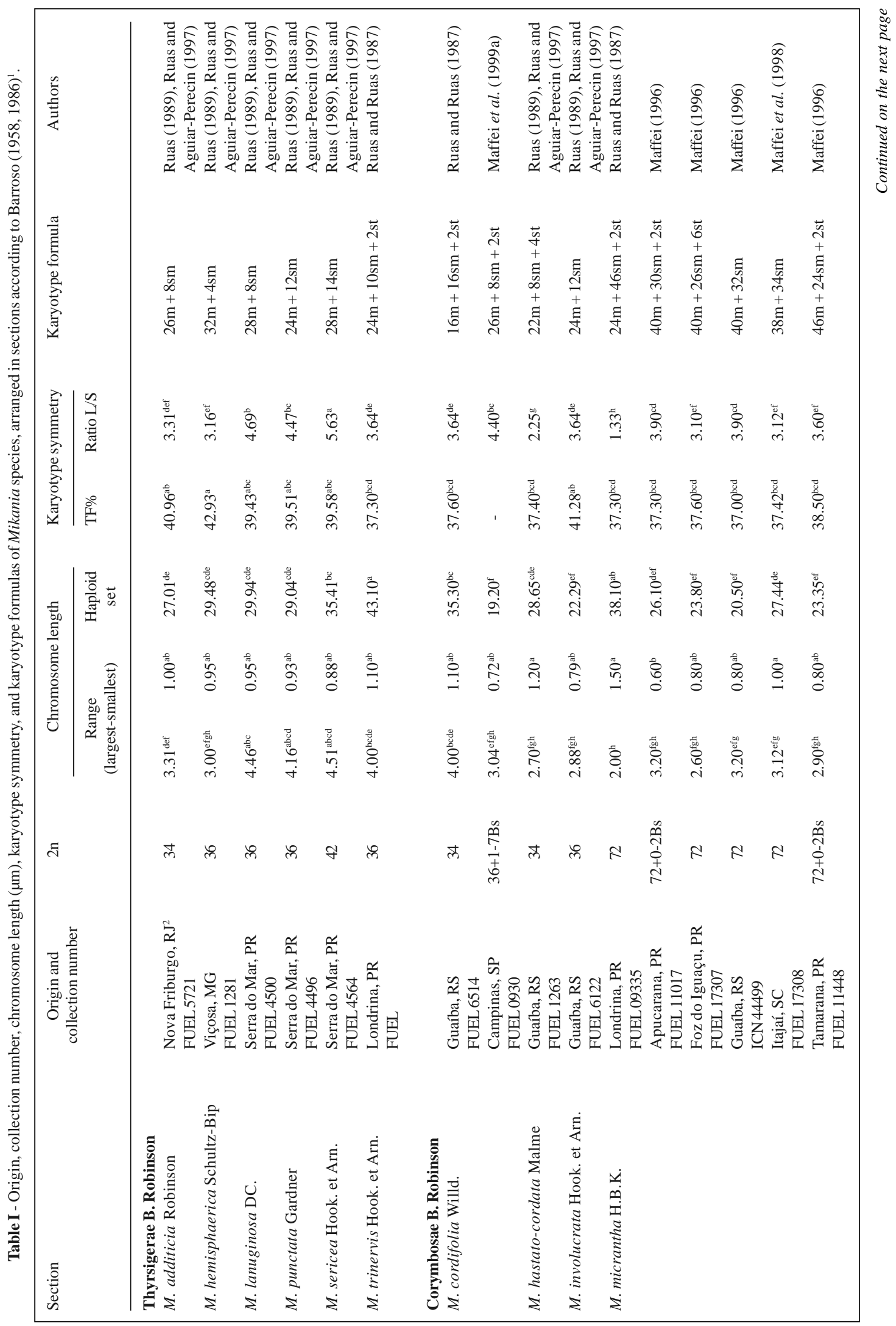




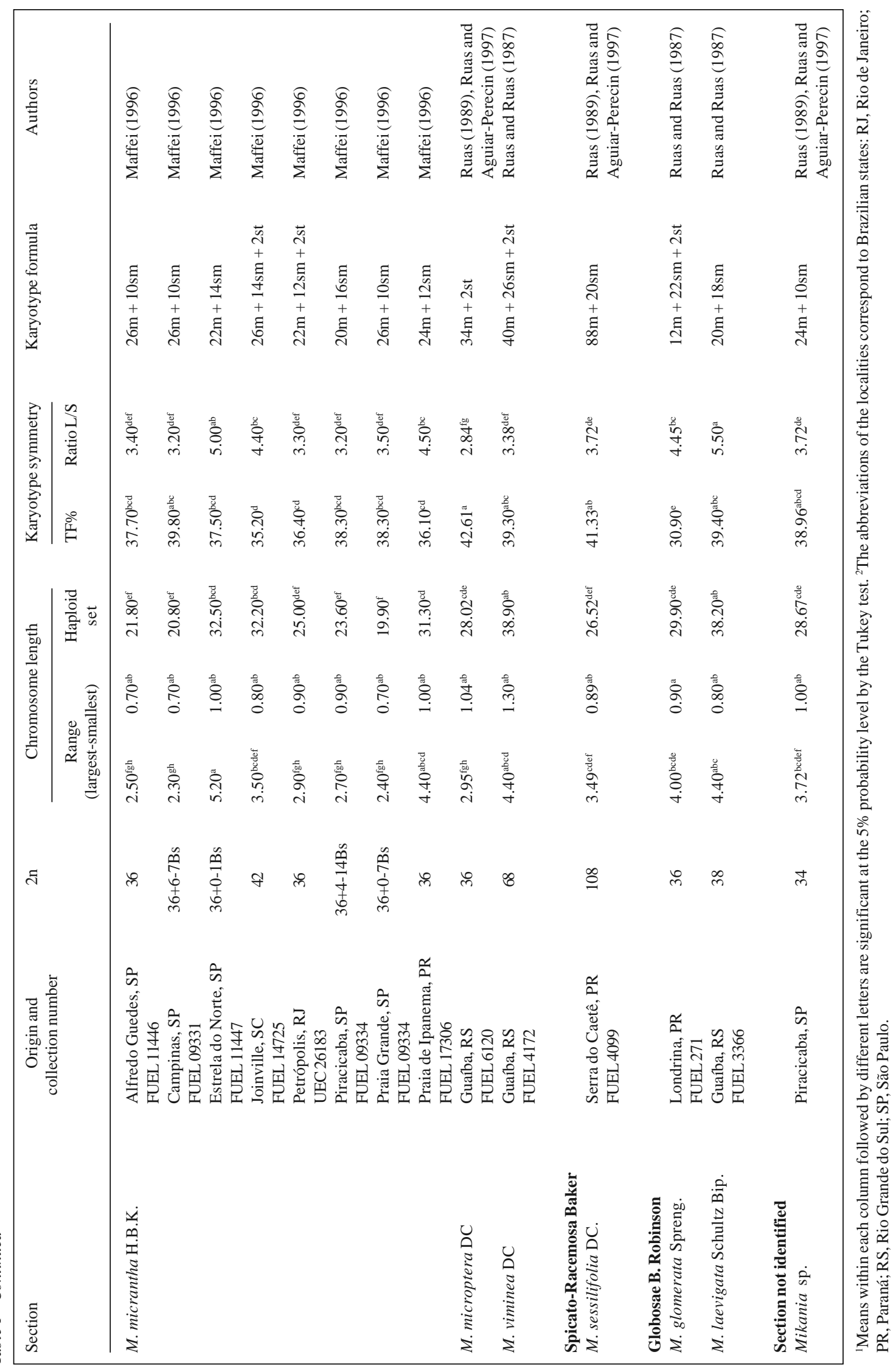


amplification or the deletion of small portions of chromatin and pericentric inversions may have occurred in this chromosome pair during karyotype evolution (Table I).

A tendency toward karyotype asymmetry was observed in all species (Table I), with M. glomerata displaying the most asymmetric karyotype of all the species so far studied, having a TF\% value of 30.90 and a ratio longest:shortest of 4.45 (Ruas and Ruas, 1987).

\section{CYTOTYPES OF M. MICRANTHA}

Fourteen cytotypes of M. micrantha were studied, all from different localities in Brazil (Ruas and Ruas, 1987; Maffei, 1996, Maffei et al., 1998, 1999b); seven were diploid, six with $2 \mathrm{n}=2 \mathrm{x}=36$ and one with $2 \mathrm{n}=2 \mathrm{x}=42$, while six were tetraploid with $2 n=4 x=72$. In all the cytotypes of M. micrantha chromosome pair 1 was the most inconstant, showing variation in both size and structure. The largest chromosomes were in cytotypes from Estrela do Norte (São Paulo State) and Praia de Ipanema (Paraná State), which also had the largest haploid sets (Table I). The population from Praia Grande (São Paulo State) had the smallest chromosomes and haploid length. This difference in chromosome size occurred in all the chromosome pairs, reflecting a gain or loss of genetic material (Maffei, 1996; Maffei et al., 1999b). Two other cytotypes (from Alfredo Guedes and Campinas), both with $2 n=36$, showed the same karyotype formula and similar haploid sets but they differed slightly in their arm-ratio values, which were probably modified by inversions (Maffei, 1996; Maffei et al., 1999b). Similar conclusions can be reached for the analysis of the six tetraploids with $2 \mathrm{n}=4 \mathrm{x}=72$ chromosomes, of which the population from Londrina showed the largest haploid set, with most of the variation between the tetraploids being represented by centromeric shifts. The differences observed among the cytotypes of $M$. micrantha do not seem to be related to adaptive variables, since populations occupying similar environments bear distinct karyotypes.

\section{KARYOTYPE EVOLUTION}

Chromosome studies show a regular aneuploid series with $\mathrm{x}=17,18,19,20$ and 21 in the genus Mikania (King et al., 1976; Robinson and King, 1977; King and Robinson, 1987; Ruas and Ruas, 1987; Ruas, 1989; Ruas and AguiarPerecin, 1997; Maffei et al., 1998, 1999a,b), with aneuploidy seeming to be an important component of chromosomal evolution in this genus.

In addition to aneuploidy, polyploidy is common in Mikania, with Ruas and Ruas (1987) having described two polyploid species, $M$. viminia $(2 \mathrm{n}=4 \mathrm{x}=68)$ and a cytotype of $M$. micrantha with $2 \mathrm{n}=4 \mathrm{x}=72$, while five other cytotypes of $M$. micrantha with $2 \mathrm{n}=4 \mathrm{x}=72$ were described by Maffei (1996) and Maffei et al. (1998, 1999b). Ruas (1989) and Ruas and Aguiar-Perecin (1997) reported a hexaploid species, $M$. sessilifolia with $2 \mathrm{n}=6 \mathrm{x}=108$; the karyotype of this species showed 18 subsets of chromosomes, each of them having three pairs of morphologically similar chromosomes, suggesting autopolyploid origin. $M$. micrantha has populations with $2 \mathrm{n}=34,36,38,40,42$, and 72 chromosomes (Powell and King, 1969; King et al., 1976; Turner, 1977; Strother, 1983; Waisman et al., 1984; Ruas and Ruas, 1987; Maffei, 1996; Maffei et al, 1998, 1999b) while $M$. cordifolia has aneuploid cytotypes with $\mathrm{n}=17$, 18, and 19 (Gaiser, 1954; Powell and King, 1969; Ruas and Ruas, 1987; Robinson et al., 1989; Maffei et al., 1999a). M. cordata and M. capricorni have counts of $\mathrm{n}=17$ and 18 (Coleman, 1968) and M. pachyphylla has counts of $n=17,18$, and 20 (Nevlin, 1969). These results demonstrate that aneuploid series and polyploidy are common at both the interspecific and intraspecific levels in the genus Mikania.

\section{C-BANDING ANALYSIS}

C-banding analysis has been applied in three diploid cytotypes of M. micrantha from Piracicaba, Campinas, and Praia Grande (Maffei, 1996; Maffei et al., 1999b) and revealed a variable pattern in the amount and distribution of heterochromatin in these cytotypes. The cytotype from Piracicaba showed a large heterochromatic block near the secondary constriction of chromosome 1 , and three other chromosome pairs had small centromeric bands, while another cytotype exhibited a block of heterochromatin located near the secondary constriction of the large arm of chromosome 1 and several other chromosomes showed centromeric C-bands. On the other hand, the cytotype from Praia Grande had only three pairs of chromosomes with very small centromeric bands and a total absence of heterochromatin in chromosome 1 . Thus, at least for the diploid cytotypes of $M$. micrantha, difference in haploid chromosome length may reside in unique and repetitive sequences of DNA.

\section{B-CHROMOSOMES}

B-chromosomes in the genus Mikania were only described in four diploid and two tetraploid cytotypes of $M$. micrantha (Maffei, 1996; Maffei et al., 1999b) and in one population of M. cordifolia from Campinas (Maffei et al., 1998); variation in number of Bs among cells of the same root meristem was observed in all the plants examined, which may be explained by nondisjunction during mitotic division of the meristem cells.

Besides the variation in number from cell to cell and among cytotypes, the B-chromosomes of $M$. micrantha diverged in size (from micro-size to about $0.8 \mu \mathrm{m}$ ) and morphology. Three morphological types were observed, $\mathrm{m}$, $\mathrm{sm}$, and st, which also varied from micro-sized in some cells to large telocentrics in other cells. A variable number of very small $\mathrm{m}$ type B-chromosomes were found in many cells of the Piracicaba cytotypes, which may be explained 
by centromere misdivision of a single unpaired B-chromosome, giving rise to two different-sized chromosomes and further derivates by deletion of parts of the arms. Since the B-chromosomes occurred in both littoral (Praia de Ipanema and Praia Grande) and high altitude (Petrópolis) populations of $M$. micrantha their presence was not adaptive.

C-banding in the diploid cytotypes from Piracicaba, Campinas, and Praia Grande showed heterochromatic Bchromosomes, and no detectable differences were observed in the C-band pattern between $\mathrm{A}$ and B-chromosomes, suggesting that there is no difference in the repetitive sequences of these two chromosome types.

\section{MORPHOLOGICAL AND CYTOLOGICAL EVOLUTION}

Lawrence (1951) suggested a series of evolutionary events to explain the origin of the different types of inflorescences found in Asteraceae. In Mikania, the inflorescence types are more complex than those observed in other genera of the tribe Eupatorieae, suggesting that this genus is evolutionarily advanced (Stebbins, 1977).

Five types of inflorescence are found in the genus Mikania, and according to Lawrence (1951) the thyrse type is the most primitive. More complex types of inflorescence such as corymbose, spicate, racemose, and glomerulate may have evolved from modifications that occurred in the thyrsoid type. The species with the thyrsoid inflorescence (section Thyrsigerae) correspond to about $48 \%$ of all species cited by Barroso (1958). As noted in Table I there is a high frequency of species with $\mathrm{x}=18$ in the Thyrsigerae section, supporting the hypothesis that $\mathrm{x}=18$ is the original basic number for Mikania, from which the other values $(17,19,20$, and 21$)$ have originated by aneuploidy. These data are in agreement with the findings of Mathew and Mathew (1983). High basic numbers, such as those observed in Mikania ( $\mathrm{x}=17,18,19,20,21)$, are considered to have originated by aneuploidy from the basic numbers of $x=7$, 8,9 , found in angiosperms (Grant, 1981). The analysis of species and cytotypes suggests that in the genus Mikania there is a correlation between chromosome numbers and inflorescence types.

\section{CONCLUDING REMARKS}

1. A secondary constriction in the long arm of chromosome 1 of all the species examined was identified as a cytological marker for the genus.

2. Analysis of the karyotypes demonstrated that chromosome rearrangements are common in the evolution of the genus Mikania at both the intraspecific and the interspecific level.

3. The chromosomic data obtained showed an aneuploid and polyploid series of $2 \mathrm{n}=34,36,38,40,42,68,72$, and 108 , which clearly demonstrated that aneuploidy and polyploidy are common in the evolutionary trend of this genus.
4. Correlation between the inflorescence types and chromosome numbers found in the genus indicated that $\mathrm{x}=$ 18 is the primitive basic chromosome number from which the others have been derived by aneuploidy $(\mathrm{x}=17,19,20$, and 21).

5. C-band analysis showed that a mechanism of DNA amplification or deletion of small segments of chromatin may be responsible by the variation observed in the size of chromosome 1.

6. B-chromosomes were observed in some cytotypes of $M$. micrantha and the C-band analysis demonstrated that these supranumerary chromosomes are heterochromatic. The same kind of heterochromatin was present in both $\mathrm{A}$ and $\mathrm{B}$ chromosomes.

7. Meristem cells showed variation in B-chromosome numbers, size and morphology, both in individual cells of the same plant and in different plants.

\section{ACKNOWLEDGMENTS}

Publication supported by FAPESP.

\section{REFERENCES}

Baquar, S.R. (1967-1968). Chromosome numbers in some vascular plants of East Pakistan. Rev. Biol. 6: 44-48.

Barroso, G.M. (1958). Mikanieae do Brasil. Arq. Jard. Bot. Rio J. 16: 237-426. Barroso, G.M. (1986). Sistemática de Angiospermas do Brasil. Vol. 3. Imprensa Universitária, Universidade Federal de Viçosa, Viçosa.

Coleman, J.R. (1968). Chromosome numbers in some Brazilian Compositae. Rhodora 70: 228-240.

Gaiser, L.O. (1954). Studies in Kuhnünae (Eupatoriae) II. J. Arnold Arb. Harv. Univ. 35: 87-133.

Grant, W. (1981). Plant Speciation. Columbia University Press, New York.

Holmes, W.C. (1995). A review preparatory to an infrageneric classification of Mikania (Tribe: Eupatorieae). In: Advances in Compositae Systematics (Hind, D.J.N. and Pope, G.V., eds.). Royal Botanic Gardens, Kew, England,pp. 239-254.

King, R.M. and Robinson, H. (1987). The genera of the Eupatorieae (Asteraceae). In: Monographs in Systematic Botany. Missouri Botanical Garden, St. Louis, MO, 22.

King, R.M., Ryhos, D.W., Powell, A.M., Raven, P.H. and Robinson, H. (1976). Chromosome numbers in Compositae XIII. Eupatorieae. Ann. MO Bot. Gard. 63: 862-888.

Lawrence, G.H.M. (1951). Taxonomy of vascular plants. Vol. 1. Macmillan, London.

Maffei, E.M.D. (1996). Análises citogenéticas em populações de Mikania micrantha HBK (Asteraceae). Master's thesis, Universidade Estadual de Londrina, Londrina, PR.

Maffei, E.M.D., Marin-Morales, M.A., Ruas, P.M. and Ruas, C.F. (1998). Cytogenetic analysis in populations of Mikania micrantha $\mathrm{HBKI}$ (Asteraceae). Naturalia 23: 61-69

Maffei, E.M.D., Marin-Morales, M.A., Ruas, P.M. and Ruas, C.F. (1999a) Numerical chromosome polymorphism in Mikania cordifolia Willd. (Asteraceae). Genet. Mol. Biol. 22: 609-612.

Maffei, E.M.D., Marin-Morales, M.A., Ruas, P.M. and Ruas, C.F. (1999b). Chromosomal polymorphism in 12 populations of Mikania micrantha (Compositae). Genet. Mol. Biol. 22: 433-444.

Mangenot, S. and Mangenot, G. (1958). Deuxième liste de nombres chromosomiques nouveaux chez diverses dicotylédones et monocotylédones d'Afrique Occidentale. Bull. Jard. Bot. 28: 315-329.

Mathew, P.M. and Mathew, A. (1983). Studies on the South Indian Compositae V. Cytotaxonomic consideration of tribes Vernonieae and Eupatorieae. Cytologia 48: 679-690. 
Mitra, K. and Datta, N. (1967). In: IOPB. Chromosome number reports. XIII. Taxon 16: 445-461.

Nauman, C.E. (1981). A reexamination of Mikania (Compositae) in Florida. Bull. Torrey Bot. Club 108: 467-471.

Nevlin, L.I. (1969). Ecology of an elfin forest in Puerto Rico. 3. Chromosome numbers of some flowering plants. J. Arnold Arbor. Harv. Univ. 50: 99-103.

Powell, A.M. and King, R.M. (1969). Chromosome numbers in the Compositae: Colombian species. A. J. Bot. 56: 116-121.

Robinson, H. and King, R.M. (1977). Eupatorieae - systematic review. In: The Biology and Chemistry of Compositae (Heywood, V.H. and Horbone, J.B., eds.). Academic Press, New York, NY, pp. 437-485.

Robinson, H., Carr, G.D., King, R.M. and Weedin, J.F. (1989). Chromosome numbers in Compositae. XVI: Eupatorieae II. Ann. MO Bot. Gard. 76: 1004-1011.

Ruas, C.F. (1989). Evolução cariotípica no gênero Mikania Willd. (Compositae). Master's thesis, Escola Superior de Agricultura "Luiz de Queiroz”, Universidade de São Paulo, Piracicaba, SP.

Ruas, C.F. and Aguiar-Perecin, M.L.R. (1997). Chromosome evolution in the genus Mikania (Compositae). Am. J. Bot. 84: 1156-1163.

Ruas, P.M. and Ruas, C.F. (1987). Karyotypes and chromosome morphol- ogy in the genus Mikania (Compositae) I. Cytologia 52: 551-558.

Sharma, A.K. and Sakar, A.K. (1967-1968). Chromosome number reports of plants in Annual Report Cytogenetics Laboratory. Department of Botany, University of Calcuta. Res. Bull. 2: 38-48.

Stebbins, G.L. (1977). Flowering Plants. Cambridge University Press, Cambridge.

Strother, J.L. (1983). More chromosome studies in Compositae. Am. J. Bot. 70: 1217-1224.

Turner, B.L. (1977). Fossil history geography. In: The Biology and Chemistry of Compositae (Heywood, K.H., Harbone, J.B. and Turner, B.L., eds.). Vol. 2. Academic Press, London.

Turner, B.L., Powell, A.M. and King, R.M. (1962). Chromosome numbers in the Compositae VI. Additional Mexican and Guatemalan species. Rhodora 64: 251-271.

Turner, B.L., Powell, A.M. and Cuatrecasas, J. (1967). Chromosome numbers in the Compositae XI. Ann. MO Bot. Gard. 54: 172-177.

Turner, B.L., Bacon, J., Urbash, L. and Simpson, B. (1979). Chromosome numbers in South American Compositae. Am. J. Bot. 66: 1973-1978.

Waisman, C.E., Rozemblum, E. and Hunziker, J.H. (1984). Estudios cariológicos en Compositae I. Darwiniana 25: 217-226. 